\title{
An Integrative Review of Home Visiting Programs for Mothers and Infants from Birth to 12 Months in Developed and Underdeveloped Countries
}

\author{
Floreliz V. Ngaya-an, PhD, RN, ${ }^{1}$ Ryan Q. De Torres, MA (Nursing), RN, ${ }^{1}$ \\ Lourdes Marie S. Tejero, $\mathrm{PhD}, \mathrm{RN}^{1}$ and Cathrine Fowler, PhD, RN² \\ ${ }^{1}$ College of Nursing, University of the Philippines Manila \\ ${ }^{2}$ Faculty of Health, University of Technology Sydney
}

\begin{abstract}
Objectives. To investigate home visiting for mothers and young infants, age birth-to-12 months, program goals, interventions used, home visitor characteristics and qualifications, and the program content and outcomes.

Methods. Electronic databases PubMed, CINAHL, ScienceDirect, and Sagepub were used. Eleven studies investigating home visiting from 2011-to-2016 were included. Studies were included if they: 1) were a primary study; 2) commenced during the antepartum or early postpartum period for mothers and finished before or when the infant was 12 months old; 3 ) and provided a description of home visiting program in terms of goal, type of home visitor, content, length, and outcomes. Data extraction included goals, activities, home visitor characteristics and qualifications, and outcomes. A descriptive approach was used to synthesize data.
\end{abstract}

Results. Home visiting impacted birth preparedness, newborn care practices, breastfeeding practices, and home environment necessary for maternal wellness and child health and development.

Conclusion. Home visits in developed and underdeveloped countries create positive outcomes for mothers and infants. It is important to understand the process in order to make it more effective.

Key Words: home visit, home visitation program, maternal and infant health

\section{INTRODUCTION}

Corresponding author: Floreliz V. Ngaya-an, PhD, RN

College of Nursing

University of the Philippines Manila

Sotejo Hall, Pedro Gil St.,

Ermita, Manila 1000, Philippines

Email: fvngayaan1@up.edu.ph
In 2009, the World Health Organization (WHO) and the United Nations International Children's Fund (UNICEF) issued a joint statement urging low-and middleincome countries to engage in home visiting for newborns, especially during the first week of life. Recommended interventions included: three home visits during the first week of life; recognition of issues that place the infant at risk; treatment or referral to address any high-risk issues; and the provision of maternal education to eliminate or reduce any infant safety risks. ${ }^{1}$ This strategy is based on studies conducted in South Africa showing a decrease in the neonatal mortality rate by 30 -to- $60 \% .^{2}$ The use of home visiting has been further supported internationally by the acknowledgment of the importance of early intervention during the first 1000 days of a child's life (from conception to the end of the first two years). ${ }^{3}$

The main focus of the reviews on home visiting has been to measure the outcomes. Sweet et al. ${ }^{4}$ conducted a meta- 
analysis on the impact of home visits to various outcomes related to family. Program characteristics that play a role in the achievement of these outcomes however, are often not fully focused on. In a review conducted to explore the impact of home visiting programs on child outcomes, Peacock et al. ${ }^{5}$ recommended looking into what dose of the intervention is most beneficial.

This study looked into the components of home visiting for mothers and infants from birth to 12 months as described in the different programs, specifically the goals of home visiting, the interventions done, the outcomes being measured, and the different home visitors that do home visits. Data generated from this study are expected to provide a clearer path for inquiries that are headed towards prescribing a model for home visits that is most beneficial.

\section{METHODS}

Integrative reviews are summaries of original research on a specific subject to provide a comprehensive understanding of the topic. ${ }^{6}$ The methodology outlined by Whittemore et al. ${ }^{6}$ was chosen for this review and includes problem identification, literature search, data evaluation, data analysis, and presentation of review findings. Integrative reviews allow for the inclusion of studies with diverse study designs. ${ }^{6}$

The search used electronic databases: PubMed, CINAHL, ScienceDirect, and Sagepub. The following keywords were entered: home visit, home visitation program, house call, mother and infant, maternal and infant health. The search was limited to works published in English from 2011-to-2016. A total of 20,506 records were retrieved and screened. After reviewing the titles and abstracts for duplicates and non-relevant works, 95 articles were examined in full text for inclusion.

Studies were included if: 1) a primary study; 2) commenced during the antepartum or early postpartum period for mothers and finished before or when the infant was 12 months old; and 3) a description of the home visiting program in terms of goal, type of home visitor, content and length, and outcomes were provided. Studies exploring home visiting programs specifically designed for mothers and babies with special needs, such as depression and prematurity respectively, were excluded. Textbooks, commentaries, editorials, and ongoing or pilot studies were also excluded.

Out of the 95 articles, 11 were identified to be eligible for inclusion. Articles included in the analysis were re-read and discussed with the four authors for quality based on relevance, rich description, methodological rigor, and study outcome. Figure 1 shows the flow selection process.

Data extraction included goals, activities, home visitor characteristics and qualifications, and outcomes. A descriptive approach was used to synthesize goals, activities, home visitor characteristics and qualifications, and outcomes.

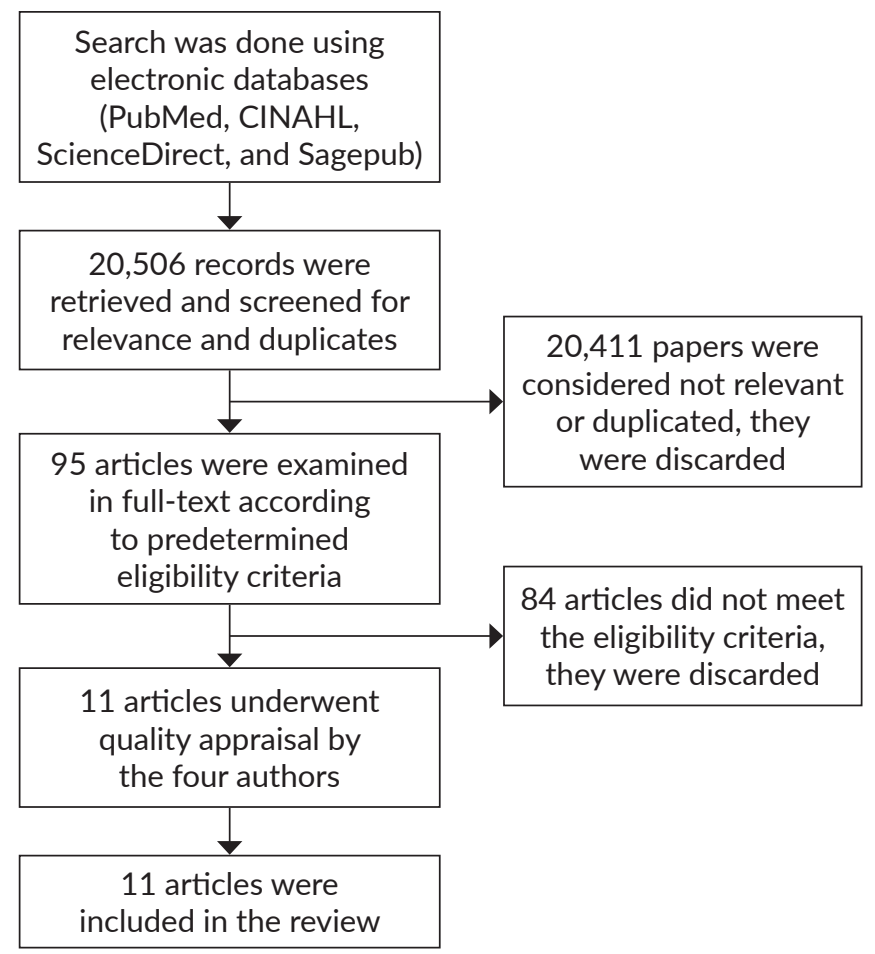

Figure 1. Flow of Selection Process.

\section{RESULTS}

\section{Characteristics of Samples}

Of the 11 studies reviewed, ten were randomized controlled trials (RCTs)., ${ }^{2,-15}$ One study used a mixed-method approach. ${ }^{16}$ Characteristics of mothers targeted within the studies were reviewed in terms of age, educational attainment, and identified risks/selection are presented in Table 1.

\section{Characteristics of Home Visiting}

Differences in the commencement, length, and frequency of home visits were identified. The intervals of the visits varied in days, weeks or months. Eight studies , $^{2,-12,14-15}$ presented home visits that started during the antenatal period. Three ${ }^{10,11-12}$ of these programs provided home visits from birth-to-12 months, while five $e^{2,8-9,14-15}$ had home visits ending when the infants were three months old or less. See Table 2 for the characteristics of home visiting programs.

For home visits that started during the postpartum period, visits commenced from the birthing facility discharge ${ }^{16}$, at $10-15$ days of life $^{13}$, or when the infant was between three-to- 12 weeks old. ${ }^{7}$

\section{Goals of Home Visiting Programs}

The home visiting programs reviewed had differing visit goals. These ranged from assessment to intervention, then evaluation of the services. Home visiting usually has the infant as the end beneficiary, but the mother directly receives the care. 
Home Visiting for Mothers and Infants

Table 1. Characteristics of Samples in Terms of Age, Educational Attainment, and Identified Risk/Selection Criteria

\begin{tabular}{|c|c|c|c|}
\hline Authors and country & Participants' age & Educational level & Risk factors/ home visiting selection criteria \\
\hline $\begin{array}{l}\text { Dodge et al. }{ }^{7} \\
\text { USA }\end{array}$ & Average age of 28.5 years & Not specified & - consenting mothers and families \\
\hline $\begin{array}{l}\text { Edwards et al. }{ }^{8} \\
\text { USA }\end{array}$ & Less than 21 years of age & Not specified & $\begin{array}{l}\text { - less than } 34 \text { weeks pregnant } \\
\text { - under } 21 \text { years } \\
\text { - did not plan surgical birth } \\
\text { - maintaining custody of the baby }\end{array}$ \\
\hline $\begin{array}{l}\text { ljumba et al. }{ }^{9} \\
\text { South Africa }\end{array}$ & 17 years and older & $\begin{array}{l}\text { Most of the mothers } \\
\text { were high school level }\end{array}$ & $\begin{array}{l}\text { - } 17 \text { years or older, } \\
\text { - lives in the cluster } \\
\text { - pregnant and intellectually capable of giving consent } \\
\text { - willing to be visited by } \mathrm{CHW} \\
\end{array}$ \\
\hline $\begin{array}{l}\text { Katz et al. }{ }^{10} \\
\text { USA }\end{array}$ & Mean age was 25 years & $\begin{array}{l}\text { Most mothers ( } 44.8 \%) \\
\text { had less than high } \\
\text { school education }\end{array}$ & $\begin{array}{l}\text { - women over age } 18 \text { who were resident of target research } \\
\text { area with inadequate prenatal care } \\
\text { - never been married (90.6\%) } \\
\text { - less than high school education ( } 44.8 \%) \\
\text { - living independently (32.5\%). }\end{array}$ \\
\hline $\begin{array}{l}\text { Kirkwood et al. }{ }^{2} \\
\text { Ghana }\end{array}$ & $\begin{array}{l}\text { Range from } \\
15-45 \text { years }\end{array}$ & Not specified & - all consenting pregnant women \\
\hline $\begin{array}{l}\text { le Roux et al. }{ }^{11} \\
\text { South Africa }\end{array}$ & Mean age was 26 years & Low educational level & $\begin{array}{l}\text { - pregnant women who were at least } 18 \text { years of old, living } \\
\text { within the target research area and able to provide consent } \\
\text { - low household income } \\
\text { - history of alcohol use while pregnant } \\
\text { - HIV-infection } \\
\text { - partner with HIV-infection }\end{array}$ \\
\hline $\begin{array}{l}\text { Meghea et al. }{ }^{12} \\
\text { USA }\end{array}$ & $\begin{array}{l}\text { Majority of mothers were } \\
\text { aged } 20-25 \text { years }\end{array}$ & $\begin{array}{l}\text { More than half had less } \\
\text { than } 12 \text { grade education }\end{array}$ & $\begin{array}{l}\text { - all consenting pregnant women } \\
\text { - most mothers were unemployed, unmarried, and had history } \\
\text { of tobacco use and physical abuse }\end{array}$ \\
\hline $\begin{array}{l}\text { Mirmolaei et al. }{ }^{13} \\
\text { Iran }\end{array}$ & $\begin{array}{l}\text { Most mothers were aged } \\
21 \text { to } 30\end{array}$ & $\begin{array}{l}\text { Most mothers had high } \\
\text { school education or less }\end{array}$ & $\begin{array}{l}\text { - woman with a healthy and term newborn in a recent low-risk } \\
\text { pregnancy } \\
\text { - recourse to the sampling environment between } 3 \text { and } 5 \text { days } \\
\text { after delivery } \\
\text { - received the first postpartum care in health service centers } \\
\text { by a general physician and a dentist } \\
\text { - ability to discuss and understand Persian language } \\
\text { - resident of any target research area } \\
\text { - first or second birth order for her infant }\end{array}$ \\
\hline $\begin{array}{l}\text { Parker et al. }{ }^{16} \\
\text { USA }\end{array}$ & 18 years or older & Not specified & $\begin{array}{l}\text { - } 18 \text { years or older } \\
\text { - legally competent } \\
\text { - read and speak English } \\
\text { - } 37+\text { weeks gestation } \\
\text { - resident in research area } \\
\end{array}$ \\
\hline $\begin{array}{l}\text { Tomlinson et al. }{ }^{14} \\
\text { South Africa }\end{array}$ & 17 years and older & $\begin{array}{l}\text { Most of the mothers } \\
\text { were high school level }\end{array}$ & - all consenting pregnant women \\
\hline $\begin{array}{l}\text { Waiswa et al. }{ }^{15} \\
\text { Uganda }\end{array}$ & aged 19 -to- 25 years & Not specified & - all consenting pregnant women \\
\hline
\end{tabular}

Goals that were predominately directed towards the mother included: newborn care and parenting development ${ }^{2,15}$; parenting self-efficacy ${ }^{7,10}$; and connections to community resources. ${ }^{7}$ Additional mother focused goals included: stress and social support ${ }^{10-11}$; improved mental status ${ }^{7,11}$; improved care-seeking behavior ${ }^{15}$; improved maternal healthy behaviors ${ }^{13}$; adherence to HIV preventive measure ${ }^{9,11,14}$; and increased satisfaction with care. ${ }^{16}$

Goals that were directed towards the infant included: neonatal wellness ${ }^{16}$; increased infant health ${ }^{11}$; better infant health outcomes ${ }^{12}$; improved infant nutrition ${ }^{8-9,11,14-15}$; and optimal infant development. ${ }^{10}$

While the study of Katz et al. ${ }^{10}$ investigated the impact of home visiting on the appropriateness of the home environment, Kirkwood et al. ${ }^{2}$ focused on reducing neonatal mortality. Edwards et al. ${ }^{8}$ investigated improving breastfeeding rates.

\section{Home Visitors}

Paraprofessionals such as community health workers (CHWs), doulas, and women volunteers conducted most visits. $2,8-12,14-15$ There were three programs that employed registered nurses. ${ }^{7,12,16}$ In the study of Parker et al. ${ }^{16}$, registered nurses with a minimum of five years maternalinfant experience were employed. One program employed masters prepared early intervention specialist to facilitate groups in partnership with paraprofessionals. ${ }^{10}$ Only one study employed trained midwives. ${ }^{13}$ 
Table 2. Home Visiting Characteristics, Goals, Home Visitor, and Content

\begin{tabular}{|c|c|c|c|c|c|c|}
\hline Author & Study Design & Home Visit Goal & Study Sample & $\begin{array}{l}\text { Home Visitor } \\
\text { and Training }\end{array}$ & Length & Content \\
\hline Dodge et al. ${ }^{7}$ & $\begin{array}{l}\text { Randomized } \\
\text { controlled } \\
\text { trial } \\
\text { evaluation }\end{array}$ & $\begin{array}{l}\text { To assess } \\
\text { family needs } \\
\text { and improve } \\
\text { connection of } \\
\text { parents with } \\
\text { community } \\
\text { resources to } \\
\text { improve infant } \\
\text { health and } \\
\text { wellbeing }\end{array}$ & $\begin{array}{l}549 \text { families } \\
\text { participated in } \\
\text { the evaluation }\end{array}$ & $\begin{array}{l}\text { - Nurses } \\
\text { - Staff member }\end{array}$ & $\begin{array}{l}\text { - One to three } \\
\text { nurse home visits } \\
\text { when the infant } \\
\text { is aged between } \\
3 \text { and } 12 \text { weeks } \\
\text { - One to two nurses } \\
\text { contact with a } \\
\text { community service } \\
\text { provider and staff } \\
\text { member telephone } \\
\text { or home follow-up } \\
\text { after } 1 \text { month }\end{array}$ & $\begin{array}{l}\text { - Family assessment } \\
\text { - Child wellbeing } \\
\text { - Community } \\
\text { resources }\end{array}$ \\
\hline Edwards et al. ${ }^{8}$ & $\begin{array}{l}\text { Randomized } \\
\text { controlled } \\
\text { trial }\end{array}$ & $\begin{array}{l}\text { To promote } \\
\text { healthy infant } \\
\text { feeding practices }\end{array}$ & $\begin{array}{l}248 \text { mothers } \\
\text { were } \\
\text { randomized } \\
\text { between } \\
\text { control and } \\
\text { intervention } \\
\text { group }\end{array}$ & $\begin{array}{l}\text { - Doulas } \\
\text { - Intensive 20-week } \\
\text { doula course } \\
\text { - Ten-week } \\
\text { breastfeeding } \\
\text { course } \\
\text { - Weekly individual } \\
\text { and group } \\
\text { supervision with a } \\
\text { pediatric nurse } \\
\end{array}$ & $\begin{array}{l}\text { - Weekly antenatal } \\
\text { visits (average } \\
10 \text { visits) } \\
\text { - Doulas present } \\
\text { at birth } \\
\text { - Visits for three } \\
\text { months postpartum } \\
\text { (average } 12 \text { visits) } \\
\text { - Provided } 24 \text {-hour } \\
\text { telephone help }\end{array}$ & $\begin{array}{l}\text { - Labor and birth, } \\
\text { maternal/infant } \\
\text { well-being, } \\
\text { breastfeeding } \\
\text { advocacy and } \\
\text { support }\end{array}$ \\
\hline ljumba et al. ${ }^{9}$ & $\begin{array}{l}\text { Cluster- } \\
\text { randomized } \\
\text { controlled } \\
\text { trial }\end{array}$ & $\begin{array}{l}\text { To promote } \\
\text { healthy infant } \\
\text { pattern }\end{array}$ & $\begin{array}{l}3,957 \text { pregnant } \\
\text { women } \\
\text { consented to } \\
\text { participate } \\
\text { in the study } \\
\text { (1,821 in the } \\
\text { intervention } \\
\text { group; } 2,136 \\
\text { in the control } \\
\text { group) }\end{array}$ & $\begin{array}{l}\text { - Community health } \\
\text { workers } \\
\text { 10-day training } \\
\text { on home entry, } \\
\text { motivational } \\
\text { interviewing, } \\
\text { breastfeeding, } \\
\text { antenatal care, } \\
\text { newborn care, } \\
\text { postnatal depression } \\
\text { - Weekly supervision } \\
\text { meetings }\end{array}$ & $\begin{array}{l}\text { Structured home } \\
\text { visiting scheduled } \\
\text { (two home visits } \\
\text { during pregnancy, } \\
\text { one in the first } 48 \\
\text { hour after birth, 3-4 } \\
\text { days, 10-14 day, 3-4 } \\
\text { weeks and last visit } \\
\text { at 8-9 weeks }\end{array}$ & $\begin{array}{l}\text { - Community-based } \\
\text { intervention } \\
\text { package } \\
\text { - Topics to discuss } \\
\text { infant feeding } \\
\end{array}$ \\
\hline Katz et al. ${ }^{10}$ & $\begin{array}{l}\text { Randomized } \\
\text { controlled } \\
\text { trial }\end{array}$ & $\begin{array}{l}\text { To provide health } \\
\text { and development } \\
\text { intervention } \\
\text { for high risk } \\
\text { African-American } \\
\text { mothers }\end{array}$ & $\begin{array}{l}286 \text { mothers } \\
\text { participated in } \\
\text { the study (140 } \\
\text { in the control } \\
\text { group; } 146 \text { in } \\
\text { the treatment } \\
\text { group) }\end{array}$ & $\begin{array}{l}\text { Paraprofessional } \\
\text { home visitors and } \\
\text { group facilitators } \\
-45 \text { day intensive } \\
\text { training } \\
\text { - Master's level } \\
\text { early intervention } \\
\text { specialist lead group } \\
\text { - no training stated }\end{array}$ & $\begin{array}{l}\text { - Home Visits weekly } \\
\text { until birth to four } \\
\text { months, biweekly } \\
\text { five-to-12 months } \\
\text { - From five months, } \\
\text { bi-weekly group } \\
\text { attendance }\end{array}$ & $\begin{array}{l}\text { - Combined home } \\
\text { visiting and group } \\
\text { intervention - } \\
\text { discussion and play } \\
\text { groups } \\
\text { - Standardized } \\
\text { curriculum } \\
\text { - Content provided } \\
\text { - Mother/infant } \\
\text { focused } \\
\end{array}$ \\
\hline Kirkwood et al. ${ }^{2}$ & $\begin{array}{l}\text { Cluster } \\
\text { randomized } \\
\text { trial }\end{array}$ & $\begin{array}{l}\text { To promote } \\
\text { newborn-care } \\
\text { practices and } \\
\text { decrease neonatal } \\
\text { mortality rate }\end{array}$ & $\begin{array}{l}16,329 \text { eligible } \\
\text { deliveries from } \\
\text { November } \\
1,2008 \text { to } \\
\text { December } 31, \\
2009 \text { were } \\
\text { included in the } \\
\text { analysis (8294 } \\
\text { in the control } \\
\text { group, } 8035 \text { in } \\
\text { the Newhints } \\
\text { intervention) }\end{array}$ & $\begin{array}{l}\text { - Community- } \\
\text { based surveillance } \\
\text { volunteers } \\
\text { - Nine-days training } \\
\text { in three-phases over } \\
\text { eight months } \\
\text { - Two-days refresher } \\
\text { training provided }\end{array}$ & $\begin{array}{l}\text { - Two home visits in } \\
\text { pregnancy and three } \\
\text { visits after birth } \\
\text { (day one, three and } \\
\text { seven) }\end{array}$ & $\begin{array}{l}\text { - Newhints an } \\
\text { integrated } \\
\text { intervention } \\
\text { package } \\
\text { - Essential newborn } \\
\text { care practices } \\
\text { - Child health and } \\
\text { surveillance }\end{array}$ \\
\hline
\end{tabular}

The paraprofessional training varied in terms of length and focus. In one study, CHWs received skills training to deliver the intended content of the home visit and other required knowledge development on maternal and child health, HIV, malnutrition, and alcohol use. ${ }^{11}$ Doulas received
20 weeks participating in an intensive doula training course and 10 weeks of breastfeeding peer counselor training program. ${ }^{8}$ In the Ghana Study, community-based surveillance volunteers were trained to identify pregnant women in their community, promote essential newborn-care practices and 
Table 2. Home Visiting Characteristics, Goals, Home Visitor, and Content (continued)

\begin{tabular}{|c|c|c|c|c|c|c|}
\hline Author & Study Design & Home Visit Goal & Study Sample & $\begin{array}{l}\text { Home Visitor } \\
\text { and Training }\end{array}$ & Length & Content \\
\hline le Roux et al. ${ }^{11}$ & $\begin{array}{l}\text { Cluster } \\
\text { randomized } \\
\text { controlled } \\
\text { trial }\end{array}$ & $\begin{array}{l}\text { To promote } \\
\text { maternal and } \\
\text { child well being }\end{array}$ & $\begin{array}{l}1,238 \text { mothers } \\
\text { (594 in the } \\
\text { standard care; } \\
644 \text { in the } \\
\text { intervention } \\
\text { group) }\end{array}$ & $\begin{array}{l}\text { - Community health } \\
\text { worker } \\
\text { - One-month } \\
\text { training using an } \\
\text { intervention manual } \\
\text { - Trained in } \\
\text { foundational skills } \\
\text { - Monthly in-service } \\
\text { training }\end{array}$ & $\begin{array}{l}\text { - Six antenatal visits } \\
\text { (range one-to-27) } \\
\text { - Five postnatal visits } \\
\text { (range one-to-12) } \\
\text { - Sessions averaged } \\
31 \text { minutes }\end{array}$ & $\begin{array}{l}\text { - Intervention manual } \\
\text { used } \\
\text { - Maternal/child } \\
\text { health promotion } \\
\text { - Child health } \\
\text { surveillance }\end{array}$ \\
\hline Meghea et al. ${ }^{12}$ & $\begin{array}{l}\text { Randomized } \\
\text { controlled } \\
\text { trial }\end{array}$ & $\begin{array}{l}\text { To evaluate } \\
\text { nurse-CHW } \\
\text { home visitation in } \\
\text { improving infant } \\
\text { health in low- } \\
\text { income families }\end{array}$ & $\begin{array}{l}613 \text { women } \\
\text { participated } \\
\text { in the study } \\
\text { (307 in the } \\
\text { intervention } \\
\text { group; } 306 \\
\text { in the control } \\
\text { group) }\end{array}$ & $\begin{array}{l}\text { - Nurses } \\
\text { - Community health } \\
\text { worker }\end{array}$ & $\begin{array}{l}\text { - Home visits during } \\
\text { pregnancy and the } \\
\text { first } 12 \text { months of } \\
\text { the infant's life }\end{array}$ & $\begin{array}{l}\text { - Prenatal and } \\
\text { postnatal program } \\
\text { - Maternal stress } \\
\text { and maternal } \\
\text { health issues } \\
\text { - Maternal and } \\
\text { child health } \\
\text { - Modules for CHW } \\
\text { were developed } \\
\end{array}$ \\
\hline Mirmolaei et al. ${ }^{13}$ & $\begin{array}{l}\text { Randomized } \\
\text { controlled } \\
\text { trial }\end{array}$ & $\begin{array}{l}\text { To promote } \\
\text { maternal healthy } \\
\text { behaviours }\end{array}$ & $\begin{array}{l}200 \text { mothers } \\
\text { (100 in the } \\
\text { intervention } \\
\text { group; } 100 \\
\text { in the control } \\
\text { group) }\end{array}$ & - Trained midwife & $\begin{array}{l}\text { Home visits were } \\
\text { delivered at 10-15 } \\
\text { and } 42-60 \text { days post } \\
\text { birth }\end{array}$ & $\begin{array}{l}\text { Maternal health } \\
\text { assessment and } \\
\text { history } \\
\text { - Health promotion } \\
\text { messages }\end{array}$ \\
\hline Parker et al. ${ }^{16}$ & $\begin{array}{l}\text { Longitudinal, } \\
\text { mixed } \\
\text { method, } \\
\text { within- } \\
\text { subject } \\
\text { design }\end{array}$ & $\begin{array}{l}\text { To promote } \\
\text { neonatal wellness } \\
\text { and breastfeeding } \\
\text { practices, and } \\
\text { decrease neonatal } \\
\text { jaundice- } \\
\text { related hospital } \\
\text { readmission, } \\
\text { and improve } \\
\text { satisfaction } \\
\text { with care }\end{array}$ & $\begin{array}{l}1,705 \text { mothers } \\
\text { agreed to } \\
\text { receive home } \\
\text { visitation }\end{array}$ & $\begin{array}{l}\text { - Registered nurses } \\
\text { experienced } \\
\text { maternal and child } \\
\text { health nurses }\end{array}$ & $\begin{array}{l}\text { - Home visits } \\
\text { one-to-four days } \\
\text { after discharge } \\
\text { for approximately } \\
90 \text { minutes } \\
\text { - If indicated, second } \\
\text { or third visits can } \\
\text { be done } \\
\text { - Second visit } \\
\text { typically occur three } \\
\text { to seven days after } \\
\text { the initial visit }\end{array}$ & $\begin{array}{l}\text { - Physical assessment } \\
\text { mother and infant } \\
\text { - Education on } \\
\text { community } \\
\text { programs and } \\
\text { resources } \\
\text { - Identification of } \\
\text { risk factors }\end{array}$ \\
\hline Tomlinson et al. ${ }^{14}$ & $\begin{array}{l}\text { Randomized } \\
\text { controlled } \\
\text { trial }\end{array}$ & $\begin{array}{l}\text { To promote } \\
\text { positive postnatal } \\
\text { outcomes }\end{array}$ & $\begin{array}{l}\text { Analysis at } 12 \\
\text { weeks involved } \\
3,561 \text { mothers } \\
\text { (1,902 in the } \\
\text { control group; } \\
1,659 \text { in the } \\
\text { intervention } \\
\text { group) }\end{array}$ & $\begin{array}{l}\text { - Trained community } \\
\text { health workers }\end{array}$ & $\begin{array}{l}\text { Seven home-based } \\
\text { visits (two during } \\
\text { pregnancy, one } \\
\text { within } 48 \text { hour of } \\
\text { birth, during days } \\
\text { 3-4 and } 10-14 \text {, } \\
\text { during weeks } 3-4 \\
\text { and } 7-8\end{array}$ & $\begin{array}{l}\text { - Prevention of } \\
\text { mother-to-child } \\
\text { transmission of HIV } \\
\text { - Integrated } \\
\text { management of } \\
\text { childhood illness } \\
\text { - Lactation counseling } \\
\text { - Antenatal } \\
\text { and postnatal } \\
\text { assessment and care }\end{array}$ \\
\hline Waiswa et al. ${ }^{15}$ & $\begin{array}{l}\text { Cluster } \\
\text { randomized } \\
\text { controlled } \\
\text { trial }\end{array}$ & $\begin{array}{l}\text { To examine the } \\
\text { impact of home } \\
\text { visitation program } \\
\text { on essential } \\
\text { newborn care } \\
\text { practices and } \\
\text { care-seeking }\end{array}$ & $\begin{array}{l}\text { At baseline, } \\
395 \text { mothers } \\
\text { were included } \\
\text { (194 in the } \\
\text { intervention } \\
\text { group; } 201 \\
\text { in the control } \\
\text { group) }\end{array}$ & $\begin{array}{l}\text { - Community health } \\
\text { workers (Women } \\
\text { and men) } \\
\text { - Five days training } \\
\text { - Reinforcement } \\
\text { of community } \\
\text { health workers' } \\
\text { knowledge and skills } \\
\text { through quarterly } \\
\text { supervisory } \\
\text { meetings and } \\
\text { directly observed } \\
\text { supervision } \\
\text { - Six-day in service } \\
\text { training was done in } \\
\text { public and private } \\
\text { health facilities }\end{array}$ & $\begin{array}{l}\text { - Two home visits } \\
\text { during pregnancy } \\
\text { and three visits } \\
\text { postnatally as } \\
\text { close to days } 1 \text {, } \\
3 \text { and } 7 \text { days }\end{array}$ & $\begin{array}{l}\text { - UNEST integrated } \\
\text { intervention } \\
\text { package } \\
\text { - Pregnancy, } \\
\text { childbirth and } \\
\text { postnatal care. } \\
\text { - Child health } \\
\text { information and } \\
\text { intervention }\end{array}$ \\
\hline
\end{tabular}


conduct infant health surveillance. ${ }^{2}$ While paraprofessional visitors participated in a 45 -day intensive training program on issues to be covered and specific content for each visit. ${ }^{10}$

\section{Content of Home Visit}

Activities conducted during home visits also vary. Many of the programs were guided by a framework or manual. 2,79-12,14-15 Assessment during the antenatal period involved maternal health and nutrition ${ }^{11}$, birth plans $^{9,14}$, and identifying danger signs that placed mother or infant at risk. ${ }^{2,11}$ Health teaching activities include healthy pregnancy behaviors ${ }^{8}$, antenatal care, and HIV prevention..$^{9,14}$ During the antenatal period, mothers were reminded about regular antenatal clinic attendance ${ }^{11}$, HIV testing, $9,11,14$, child care ${ }^{9,14}$, and early and exclusive breastfeeding. $2,8-9,11,14$

During the postnatal period, the assessment included maternal physical condition, ${ }^{13,16}$ and the child's health. ${ }^{16}$ Home visitors assessed breastfeeding practices ${ }^{2,8-9,11,14,16}$, monitored child growth ${ }^{11}$, and emphasized extra care for low birth weight babies. ${ }^{914}$ Skin-to-skin care, together with latching, positioning, relieving physical discomforts were taught ${ }^{8}$, and information about mother-infant bonding was provided. ${ }^{9,11,14}$ Another important aspect of postpartum visits involved encouraging mothers to immunize their babies. ${ }^{11}$

Women were assisted to adjust to parenthood.,10 Instructions on various parenting health practices were given. ${ }^{10}$ Parenting competencies ${ }^{7,10}$ and child care topics in accordance with age and development ${ }^{10,16}$ were emphasized during visits. The mothers were encouraged to make the most of local and social networks and community services/ resources. ${ }^{16}$ Home safety, water safety, fire safety, and safe sleep practices were also emphasized. ${ }^{16}$

\section{Outcomes of Home Visit}

Outcomes can be summarized into the following: improved birth preparedness; newborn care practices; improved breastfeeding practices; improved home environment necessary for maternal wellness and child health and development; and improved mental health status. Results demonstrated significant improvements in birth preparedness and essential newborn care practices such as breastfeeding, hygienic cord care, and thermal protection. ${ }^{15}$ There were greater improvements in newborn care practices particularly immediate breastfeeding, exclusive breastfeeding in the first three days of life, and clean hands for a home birth. ${ }^{2}$

Several studies focused largely on breastfeeding practices as an outcome. It was identified that home visiting resulted in: higher breastfeeding initiation rates $^{2,16}$; increased rates of those who attempted to breastfeed ${ }^{8}$; higher prevalence of exclusive breastfeeding at 12 weeks ${ }^{9,14}$; use of one feeding method for six months ${ }^{11}$; breastfeeding for six months ${ }^{16}$; and mothers were more likely to breastfeed for more than six months. ${ }^{8}$ Home visiting also resulted in fewer mothers introducing complementary food before six weeks, while more waited until four months. ${ }^{8}$
Results of the studies identified that mothers had: improved maternal healthy behaviors ${ }^{13}$; better parenting behaviors ${ }^{7}$; and improved home environments necessary for promoting child development. ${ }^{7,10}$ Results also demonstrated an increase in condom use ${ }^{11}$ and lower reports of clinical anxiety. $^{7}$ Qualitative findings in the study of Parker et al. ${ }^{16}$ stated that new mothers described home visiting as comforting, informative, knowledgeable, supportive or reassuring, helpful, great, and positive.

Home visiting was found to impact birth outcomes such as healthy height for age measurements ${ }^{11}$ and in some studies, low birth weight babies were given Kangaroo Mother Care. ${ }^{9,14}$ In some instance, babies identified as high risk were taken outside the home for care e.g. ${ }^{15}$

In the study of le Roux et al. ${ }^{11}$, it was found that fathers were likely to acknowledge the infant and be more involved with their care as a result of the home-visiting intervention. Katz et al. ${ }^{10}$ stated that paraprofessional home visitors can be successful in improving child-rearing environments and parenting attitudes. Further, Katz et al. ${ }^{10}$ explained that paraprofessionals are a less costly workforce option.

\section{DISCUSSION}

Child health and development are key factors in improving the life trajectory of a child and contribute to a positive future for the communities in which they live. ${ }^{17}$ Investment in early childhood development and health will potentially reduce the inequities that result in poverty, limited education and poor nutrition and illness. ${ }^{18}$ While there are many types of successful evidence-based home visiting programs, these programs are mainly offered in high-income countries, extending into the second year of life or longer, and are frequently staffed by professionals. ${ }^{19}$ In low-income countries, providing home visiting services to this standard may not be viable due to the number of families requiring these services, lack of professional worker availability, and a lack of funding. Sustainability of home visiting programs is a significant issue in low-income countries.

The focus of home visiting for mothers and infants are mainly directed towards the capacity of mothers to provide the infant with adequate and appropriate care. ${ }^{9,11,14}$ The mother is frequently identified as the direct target of care with interventions implemented to improve her physical, mental, and emotional health, the home environment, and family processes, with an end goal to positively impact the infant's growth and development. These are important considerations for the development, implementation, and evaluation of home visiting programs.

A limitation of the programs is the lack of active involvement of the father and other family members. ${ }^{20}$ Nevertheless, fathers and families play a significant role as they are potentially supportive or disruptive towards the intended processes and outcomes. ${ }^{21}$ In particular, a heightened awareness has occurred of the importance of 
paternal mental health during the perinatal period and their child's early years of life. ${ }^{22}$ The potentially harmful impact of paternal mental illness on the child's brain development and future health is now well documented. ${ }^{23}$ These understanding highlight the need for inclusion of fathers in home visiting programs especially around mental health assessment and if necessary the referral and/or active involvement in home visiting interventions.

The acknowledgment of the father and significant others' role in the care of the mother and infant was minimal. This lack of inclusion may not reflect what actually occurred in the home visits but they need to be included when conceptualizing program strategies to enable successful implementation and integration of interventions and childcare practices into family life.

Important details such as the training and preparations of the home visitors, specific content or activities during home visits, need to be carefully documented and described in the literature. Many of the programs appear to be guided by a manual which is critical to maintaining the fidelity of the home visiting program, ${ }^{19,24}$ though it is thought that many home-visiting programs depart from the approach advocated by the manual with variations that include the provision of core services and linkage to core community resources. ${ }^{20}$

Investigations into the competencies needed by nurses to successfully deliver sustained home visiting programs have been identified by Kemp et al..$^{25}$ These home visiting competencies in addition to existing nursing competencies are: “... (a) enhanced knowledge of child development, social determinants of health, and broader outcomes for individuals and populations; (b) advanced skills in fine observation, anticipatory guidance, negotiating, modeling and experimentation, holistic case management, and working in interdisciplinary teams; and (c) attitudinal competency for working with and supporting risk-taking".

Nurses are the likely group to be employed in this strategy as they can readily provide the needed support and knowledge. Olds et al. ${ }^{26}$ found that paraprofessional home visitors produce smaller effects than nurses for maternal and infant outcomes. Nevertheless, in resource-limited settings paraprofessionals, doulas, community health workers, and women volunteers are the main service providers. They are often part of the community and not as expensive as employing nurses and other professionals. Issues could arise as paraprofessionals have limitations in regards to activities they can or cannot do. There is a need to explore essential tasks during home visits and find a balance between cost-effectiveness and relevance of intervention and provider. Further research is needed as to the essential competencies needed for non-nurse home visiting to ensure safe outcomes for mothers and their infants.

\section{CONCLUSION}

Home visiting promotes a holistic approach of attending to the needs and concerns of mothers, infants, and families.
Home visitors gain opportunities to observe and assess the realities of their situations which is helpful in tailor fitting interventions. Also, home visitors are able to establish trust and create a positive working relationship in a controlled and familiar environment. This is essential in encouraging active participation and promoting optimal support and learning for mothers to acquire knowledge, skills, and attitude towards achieving and maintaining health and wellness.

Home visiting programs in developed and underdeveloped countries create positive outcomes for mothers and infants. It is important to understand the process in order to make it more effective. A limitation of these studies is a lack of a uniform method of delivering services, measuring outcomes and the long-term impact of home visiting. While making recommendations as to "dose" of intervention considered most beneficial, as was the gap in the literature, this study was able to look closer into the different components of home visiting. The information generated from this study may be used to provide a clearer path for inquiries that are geared towards prescribing a model for a home visit that is most beneficial.

\section{Statement of Authorship}

All authors participated in data collection and analysis, and approved the final version submitted.

\section{Author Disclosure}

All authors declared no conflicts of interest.

\section{Funding Source}

This paper was part of a dissertation grant given by the UP Manila NGOHS, CHED and UP College of Nursing Foundation Incorporated.

\section{REFERENCES}

1. World Health Organization, WHO/UNICEF Joint Statement: Home Visits for the newborn child: a strategy to improve survival [Internet]. 2009 [cited 2017 Oct]. Available from: http://apps.who. int/iris/bitstream/10665/70002/1/WHO_FCH_CAH_09.02_eng. pdf ?ua $=18 u a=1$

2. Kirkwood BR, Manu A, ten Asbroek AH, Soremekun S, Weobong B, Gyan T, et al. Effect of the Newhints home-visits intervention on neonatal mortality rate and care practices in Ghana: a cluster randomised controlled trial. Lancet. 2013 Jun; 381(9884):2184-92. doi: 10.1016/S0140-6736(13)60095-1.

3. Lo S, Das P, Horton R. A good start in life will ensure a sustainable future for all. Lancet. 2017 Jan; 389(10064):8-9. doi: 10.1016/S01406736(16)31774-3.

4. Sweet MA, Appelbaum MI. Is home visiting an effective strategy? A meta-analytic review of home visiting programs for families with young children. Child Dev. 2004 Sep-Oct; 75(5):1435-56. doi: 10.1111/j.1467-8624.2004.00750.x.

5. Peacock S, Konrad S, Watson E, Nickel D, Muhajarine N. Effectiveness of home visiting programs on child outcomes: a systematic review. BMC Public Health. 2013 Jan; 13(1):17. doi: 10.1186/1471-245813-17.

6. Whittemore R, Knafl K. The integrative review: updated methodology. J Adv Nurs. 2005 Dec; 52(5):546-53. doi: 10.1111/j.1365-2648. 2005.03621.x. 
7. Dodge KA, Goodman WB, Murphy RA, O'Donnell K, Sato J, Guptill $\mathrm{S}$. Implementation and randomized controlled trial evaluation of universal postnatal nurse home visiting. Am J Public Health. 2014 Feb; 104 (Suppl 1):S136-43. doi:10.2105/AJPH.2013.301361

8. Edwards RC, Thullen MJ, Korfmacher J, Lantos JD, Henson LG, Hans SL. Breastfeeding and complementary food: randomized trial of community doula home visiting. Pediatrics. 2013 Nov; 132 (Supplement 2):S160-6. doi:10.1542/peds.2013-1021P

9. Ijumba P,Doherty T, Jackson D, Tomlinson M, Sanders D, Swanevelder $\mathrm{S}$, et al. Effect of an integrated community-based package for maternal and newborn care on feeding patterns during the first 12 weeks of life: a cluster-randomized trial in a South African township. Public Health Nutr. 2015 Oct; 18(14):2660-8. doi: 10.1017/S1368980015000099.

10. Katz KS, Jarrett MH, El-Mohandes AA, Schneider S, McNeelyJohnson D, Kiely M. Effectiveness of a combined home visiting and group intervention for low income African American mothers: the pride in parenting program. Matern Child Health J. 2011 Dec; 15 Suppl 1:S75-84. doi 10.1007/s10995-011-0858-x

11. le Roux IM, Tomlinson M, Harwood JM, O'Connor MJ, Worthman $\mathrm{CM}, \mathrm{Mbewu} \mathrm{N}$, et al. Outcomes of home visits for pregnant mothers and their infants: a cluster randomised controlled trial. AIDS. 2013 Jun; 27(9):1461-71. doi:10.1097/QAD.0b013e3283601b53

12. Meghea CI, Li B, Zhu Q, Raffo JE, Lindsay JK, Moore JS, et al. Infant health effects of a nurse-community health worker home visitation programme: A randomized controlled trial. Child Care Health Dev. 2013 Jan; 39(1):27-35. doi:10.1111/j.1365-2214.2012.01370.x

13. Mirmolaei ST, Valizadeh MA, Mahmoodi M, Tavakol Z. Comparison of effects of home visits and routine postpartum care on the healthy behaviors of Iranian low-risk mothers. Int J Prev Med. 2014 Jan;5(1):61-8.

14. Tomlinson M, Doherty T, Ijumba P, Jackson D, Lawn J, Persson LA, et al. Goodstart: a cluster randomised effectiveness trial of an integrated, community-based package for maternal and newborn care, with prevention of mother-to-child transmission of HIV in a South African township. Trop Med Int Health. 2014 Mar; 19(3):256-66. doi:10.1111/tmi.12257

15. Waiswa P, Pariyo G, Kallander K, Akuze J, Namazzi G, EkirapaKiracho E, et al. Effect of the Uganda Newborn Study on care-seeking and care practices: a cluster-randomised controlled trial. Glob Health Action. 2015 Mar; 8(1):24584. doi: 10.3402/gha.v8.24584.

16. Parker C, Warmuskerken G, Sinclair L. Enhancing neonatal wellness with home visitation. Nurs Womens Health. 2015 Feb-Mar; 19(1): 36-45. doi: 10.1111/1751-486X.12174
17. Lu C, Black MM, Richter LM. Risk of poor development in young children in low-income and middle-income countries: an estimation and analysis at the global, regional, and country level. Lancet Glob Health. 2016 Dec; 4(12):e916-22. doi: 10.1016/S2214109X(16)30266-2.

18. Engle PL, Fernald LC, Alderman H, Behrman J, O'Gara C, Yousafzai A, et al. Strategies for reducing inequalities and improving developmental outcomes for young children in low-income and middle-income countries. Lancet. 2011 Oct; 378(9799):1339-53. doi: 10.1016/S0140-6736(11)60889-1.

19. Olds D, Hill P, Robinson J, Song N, Little C. Update on home visiting for pregnant women and parents of young children. Curr Probl Pediatr. 2000 Apr; 30(4):107-41. doi: 10.1067/mps.2000.105091.

20. Duggan A,Fuddy L,McFarlane E,Burrell L, Windham A, Higman S, et al. Evaluating a statewide home visiting program to prevent child abuse in at-risk families of newborns: Fathers' participation and outcomes. Child Maltreat. 2004 Feb; 9(1):3-17. doi: 10.1177/1077559503261336.

21. Fisher SD. Paternal mental health: why is it relevant? Am J Lifestyle Med. 2016 Feb; 11(3):200-11. doi: 10.1177/1559827616629895.

22. Vänskä M, Punamäki RL, Tolvanen A, Lindblom J, Flykt M, Unkila-Kallio L, et al. Paternal mental health trajectory classes and early fathering experiences: Prospective study on a normative and formerly infertile sample. Int J Behav Dev. 2017 Sep; 41(5):570-80. https://doi.org/10.1177/0165025416654301

23. Garfield CF, Duncan G, Rutsohn J, McDade TW, Adam EK, Coley RL, et al. A longitudinal study of paternal mental health during transition to fatherhood as young adults. Pediatrics. 2014 May; 133(5): 836-43. doi: 10.1542/peds.2013-3262.

24. Paulsell D, Del Grosso P, Supplee L. Supporting replication and scale-up of evidence-based home visiting programs: assessing the implementation knowledge base. Am J Public Health. 2014 Sep;104(9):1624-32. doi: 10.2105/AJPH.2014.301962.

25. Kemp L, Anderson T, Travaglia J, Harris E. Sustained nurse home visiting in early childhood: exploring Australian nursing competencies. Public Health Nurs. 2005 May-Jun; 22(3):254-9. doi: 10.1111/ j.0737-1209.2005.220309.x.

26. Olds DL, Robinson J, O'Brien R, Luckey DW, Pettitt LM, Henderson $\mathrm{Jr} \mathrm{CR}$, et al. Home visiting by paraprofessionals and by nurses: a randomized, controlled trial. Pediatrics. 2002 Sep; 110(3):486-96. doi: 10.1542/peds.110.3.486. 